\title{
A szemmozgáskövetés története és felhasználási lehető- ségeinek bemutatása az e-kereskedelemben
}

A szemmozgáskövetés technológiáját ma már egyre több kutatásban használják, hiszen alkalmazásával lehetővé válik a vizuális ingerekre adott tudattalan reakciók mérése, ami lehetővé teszi az egyén viselkedésének átfogó megismerését. A kutatók a technológiát kezdetben a látás és olvasás folyamatainak megértésére használták, ma már azonban gyakran jelenik meg mint kiegészítő pszichofiziológiai módszer a marketing, valamint a web- és szoftverergonómia különböző területein is. A szemmozgáskövetés segítségével feltárhatók a termékhasználat nehézségei és tanulmányozhatók a fogyasztói döntések mögött rejlő kognitív folyamatok, így a módszertan az elektronikus kereskedelem webes felületeinek fejlesztésében is kulcsszerepet tölthet be. Jelen cikk a szemmozgáskövetés történelmét és e-kereskedelemben történő alkalmazási lehetőségeit mutatja be két hazai vállalkozás webáruházának példáján keresztül, hogy az elméleti ismeretek összefoglalása mellett gyakorlati útmutatást adjon az ipari szereplők számára is.

Kulcsszavak: szemmozgáskövetés, e-kereskedelem, használhatósági vizsgálat, esettanulmányok

\section{A szerző(k)ről}

Szabó Bálint Gazdaság- és Társadalomtudományi Kar, Ergonómia és Pszichológia Tanszék

Így hivatkozzon erre a cikkre:

Szabó Bálint „A szemmozgáskövetés története és felhasználási lehetőségeinek bemutatása az e-kereskedelemben”, Információs Társadalom, XX. évf. (2020) 1. szám, 127-151.

$=$ https://dx.doi.org/10.22503/inftars.XX.2020.1.6

A folyóiratban közölt müvek

a Creative Commons Nevezd meg! - Ne add el! - Így add tovább! 4.0

Nemzetközi Licenc feltételeinek megfelelóen használhatók. 


\section{The story of eye tracking and its possible applications in e-commerce}

The use of eye tracking technology in research is rapidly increasing since it enables scientists to measure visually induced unconscious responses, what allows a comprehensive understanding of individual behavior. In the past, the technology was used to understand the processes of vision and reading better. Nowadays, eye tracking frequently appears as an additional psychophysiological method being used in marketing and different areas of software ergonomics. Eye tracking can unravel the difficulties of the use of the products, and cognitive processes behind consumer decisions can be analyzed by means of it, so the methodology can have a key role in the development of online platforms in e-commerce. This article presents the potential applications of eye tracking in e-commerce through the illustration of two domestic enterprises' webshop to give practical guidance alongside summarizing theoretical knowledge for industrial purposes.

Keywords: eye tracking, e-commerce, usability testing, case studies 


\section{Bevezetés: A szemmozgáskövetés története}

A szemmozgáskövetés (eye tracking) egy olyan technológia, amely lehetővé teszi a tekintet irányának pontos mérését. Az ehhez használt eszközök alkalmazási területei mára már rendkívül sokrétűek.

A szemmozgáskövetés történelme az 1800-as évektől követhető nyomon. Kezdetben a szemmozgások tanulmányozása az olvasás folyamatának pontos megismerése érdekében közvetlen megfigyeléseken alapult. 1879-ben Louis Émile Javal tükrök használatával állapította meg, hogy a szem olvasás közben nem mozog folyamatosan (balról jobbra), hanem apró ugrásokat (szakkádokat) végez, miközben az olvasott sor több pontján megáll (fixál) (Richardson és Spivey 2004).

A kezdeti empirikus vizsgálatok során a kísérleti személyek egy szemmel olvastak. Javal akkoriban a másik (zárt) szemhéjhoz rögzített mikrofon segítségével tudta megállapítani a fixációk darabszámát, hiszen a szakkádmozgások végét egyértelmüen meghatározta az pillanat, amikor a szaruhártya domború része a mikrofonnak ütközött. A mérések során továbbá erős fénnyel világították meg a kísérletben résztvevők szemét, akik az így keletkező pontszerü utókép helyzetének jelentésével adták meg a fixációk körülbelüli helyzetét az olvasott szövegen (Tinker 1928). Mivel ez a megfigyelésalapú módszer meglehetősen pontatlan volt, a kutatók 1898-ban olyan mérései technikák kialakításával kísérleteztek, amelyek a pontosság javítására irányultak. Huey (1908) például viaszból készült lemezt használva, ráharapásos módszer segítségével biztosította a fejmozgások kiküszöbölését. Delaberre pedig a megfigyeléses módszert leváltva a szemmozgás-követéses invazív mérések úttörőjeként a szemet kokainnal érzéstelenítette, amihez egy apró (középen lyukas) fogantyút rögzített, és a szemmozgást kimográffal ábrázolta (Delabarre 1898).

Az első olyan (nem-invazív) mérési technika, ahol a mérőeszköz nem érintkezett a szemmel 1901-ben valósult meg. Dodge és Cline (1901) felismerte, hogy a szem nem tökéletes gömb, ezért nem a középpontja körül forog. Az általuk kidolgozott módszer a szaruhártyáról visszatükröződő fény képének fotografikus rögzítésén alapult, amely meghatározta a szemmozgáskövetés történelmének következő 70 évet.

Mivel a fejet a vizsgálat idejére mozdulatlanul kellett tartani, a technológia eleinte alkalmatlan volt a mindennapi tevékenységek tanulmányozására. Ugyanakkor a kutatók képesek voltak vele statikus események vizsgálatára. Buswell (1920) szemmozgásokat rögzített hangos olvasás közben, Butsch (1932) pedig a gépelés folyamatát tanulmányozta a technológia segítségével. Néhány évvel később sor került a szemmozgások képek nézegetése közbeni vizsgálatára is Buswell (1935) által, Weaver (1943) pedig kottaolvasás közben elemezte a zongoristák viselkedését (Van Nuys és Weaver 1943).

A binokuláris szemmozgás rögzítésére először 1951-ben adódott lehetőség Riggs és Ratliff újításának köszönhetően, akik a mérésekhez már kontaktlencséket használtak (Riggs és Ratliff 1951; Stevenson et al. 2016). A módszer legna- 
gyobb hátránya, hogy a speciális lencsék viselete megnehezítette a pislogást, így igen kényelmetlen volt a kísérleti személyek számára, ugyanakkor ez a technológia a korábbiakkal ellentétben már lehetővé tette a fej kismértékű mozgását.

Az ember-számítógép interakció szempontjából igazi áttörés 1958-ban következett be. Mackworth és Thomas (1962) kifejlesztettek egy olyan rendszert, amely lehetővé tette a változó vizuális ingeranyag tanulmányozását (Jacob és Karn 2002). Ez, a kutatópáros által kifejlesztett, fejre szerelhető szemmozgáskövető berendezés már jóval fejlettebb volt, mint a korábbi évek találmányai, amely a fej kisebb mértékű mozgásával is együtt tudott dolgozni. Ettől az eszköz még mindig egy igen nehéz, pontatlan és kis látószögű (körülbelül $2^{\circ}$-os) berendezésnek számított. A technológiai fejlődésének köszönhetően ennél a fejre erősített változatnál a kamera már egyszerre rögzítette (filmre) a kísérleti személy látóterét és a szaruhártyáról történő visszatükröződést.

Az 1960-as években a szemmozgás-követéses technológia az invazív módszerek reneszánszát élte, amikor is a kutatók rájöttek, hogy a Delaberre-féle módszer továbbfejlesztéseként a különböző szerkezeteket szívóerő segítségével tudják szorosan a szemhez rögzíteni. Ezért Yarbus (1965) egy apró szelepet használt a szem kontaktlencse alatti víztelenítésére, Fender (1964) pedig megállapította a nátrium-hidrogén-karbonát alkalmazásának hasznosságát, mivel az átdiffundálva a szem szövetén ozmotikus szívóerőt hoz létre. Ezeknél a módszereknél a visszatükröződések rögzítését lencséhez illesztett apró tükrök segítségével valósították meg. Később a tükröket már belógatták a szem elé annak érdekében, hogy a szemet irritáló tükrök következtében keletkező könnycseppek ne homályosítják el a felvételeket. Ezekre a tükörtartó pálcákra különféle fényforrásokat (kisméretű lámpákat vagy világító radioaktív tríciumot) lógattak, hogy ezekkel generáljanak szaruhártya-visszatükröződéseket. A szemmozgások rögzítésére 1969-ben végül egy nem optikai módszert is alkalmaztak egy lencsébe épített mágneses tekercs segítségével. Ennél a módszernél a fejre mezőtekercs párokat rögzítettek, amelyek a szemre helyezett kis tekercsben áramot indukáltak, ami így a szem mozgásáról is információt adott. A vizsgálat hátránya, hogy ez a speciális kontaktlencse csak lokális (szemcseppel történő) érzéstelenítés után helyezhető fel, és mindössze körülbelül 30-60 percig tolerálható, ezért leginkább állatkísérletekben alkalmazzák (Gulyas 2009).

Az 1970-es években új irányzat alakult ki, mely során a szemmozgásokat videokamerával vizsgálták, és a mérések során rögzített jellemzőket elektronikusan határozták meg. Mivel ezek a módszerek igen érzékenyek voltak a nagy kontrasztra, így a corneoscleralis határ (az ínhártya és a szivárványhártya közötti határvonal) azonosításán alapultak. Ha a rendszer fényérzékelő szenzorai a corneoscleralis határ közelében helyezkednek el, akkor a kimenetén keletkező jel az ínhártya (szemfehérje) megvilágításának függvényében fog változni. Ezzel a módszerrel a horizontális szemmozgások azonnal meghatározhatók voltak (Young 1970), de a függőlegesek már nehezen (mivel a szemfehérje nagy, és gyakran eltakarja a szemhéj a pislogások következtében). 
Az alternatív mérési eljárás már a pupilláról történő fény visszaverődésének a hiányán alapult, ami a sötét szemszínek esetén okozott problémát az írisz és a pupilla között fellépő alacsony kontrasztkülönbség miatt. Ha a pupillát közvetlenül a pupillára merőleges fényforrás segítségével világítjuk meg, akkor a fény a retina hátsó részéről visszaverődve igen élesen látszik, ami így könnyebben észlelhető a videokamerák számára (Merchant, Morrissette és Porterfield 1974).

Az említett módszerek már kiválóan alkalmasak voltak arra, hogy meghatározzák a szem fejhez viszonyított mozgását, de a tekintet irányának a külvilágban történő pontos megállapításához a fejet szinte mozdulatlanul kellett tartani. Ennek a korlátozásnak egy néhány évvel későbbi innováció vetett véget, amely már párhuzamosan monitorozta a mozgó szem két optikai jellemzőjét.

A Merchant- és Morrisette-féle módszer segítségével tehát meghatározhatóvá vált a pupilla és annak a közepe, ezzel együtt a szaruhártya legfényesebb pontja is. Mivel ennek a pontnak a pozíciója a pupilla középpontjához képest változatlan a fej elfordítása során, miközben a szemmel is együtt mozog, így ezen a PCCR (Pupil Center Cornea Reflex) elven a tekintet iránya már a fej kisebb mozgása mellett is pontosan meghatározhatóvá vált (1. ábra).

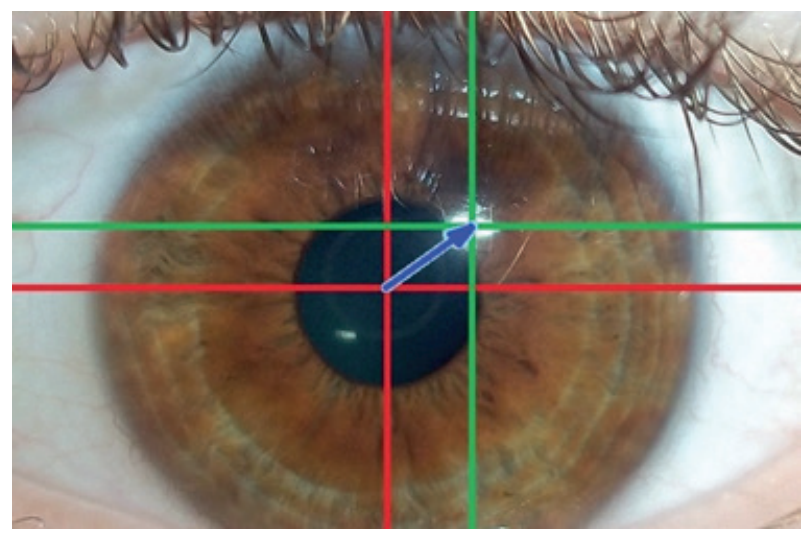

1. ábra: A PCCR mérési elv bemutatása

A ’70-es évek szemmozgás-követéses rendszerei (például a Honeywell-féle szemmozgáskövető) már ezen a nem-invazív elven működtek, és képesek voltak meghatározni, hova esik a felhasználó tekintete a képernyőn.

Egy másik módszer, mely szintén a szem fényreflexióra képes felületéről visszatükröződött fény használatán alapult, a Purkinje-képek vizsgálata (Cornsweet és Crane 1973). E módszer során a megvilágításkor és visszatükröződéskor négy különböző kép jelent meg a szaruhártya külső (P1), illetve belső (P2), valamint a szemlencse külső (P3), illetve belső felületéről (P4) visszatürköződve. Ezek közül a P1 és P4 képek egymáshoz való relatív elmozdulása szervomotorokkal mozgatott tükörrendszer segítségével volt meghatározható. A képi feldolgozáshoz használt számítógép teljesítményétől függően ez a 
rendszer már 300 és $1000 \mathrm{~Hz}$ közötti mintavételre volt képes, de a vizsgálat közben a fejet továbbra is mozdulatlanul kellett tartani.

Jól látható tehát, hogy technológiai alapon csoportosítva megkülönböztethetőek egymástól a különféle kontaktlencse-típusú és video-okulográfián alapuló (VOG) eljárások (Lupu és Ungureanu 2013), amelyek mellett még az elektro-okulográfiás (EOG) módszerek töltenek be jelentősebb szerepet. Ez utóbbiak (EOG mérések) a testen belüli, élettani folyamatok következtében kialakuló elektromos feszültség mérésén alapulnak (Patmore és Knapp 1998). A retinában található idegek sűrű elhelyezkedése miatt a szem polarizált, így azok elmozdulása esetén a környező szövetekben keletkező potenciálkülönbségek mérésével a szem helyzete meghatározható. Ezt a módszert azonban a vizsgálat intruzív jellege miatt inkább orvosi vizsgálatok során használják, így például az alvás során fellépő gyors szemmozgások (REM) rögzítésére.

A kontaktlencse-típusú eszközökkel történő vizsgálatok, invazív jellegük miatt, meglehetősen rövid ideig alkalmazhatók és kényelmetlenek is, így nem meglepő, hogy manapság a video-okulográfián alapuló módszerek a legelterjedtebbnek a különböző vizsgálati környezetekre adaptálhatóságuk miatt.

Ezeket a módszereket is többféleképpen lehet csoportosítani, hiszen a mérés során alkalmazott fény természete alapján megkülönböztethetőek egymástól a látható fénytartományban müködő, illetve az infravörös fényt használó rendszerek. Mivel a videofeldolgozás során a rendszer a szem vizuális sajátosságait detektálja (elsősorban az írisz kontúrját keresve), majd ennek a mozgásából számítja ki a tekintet irányát, így a vizsgálat sikere nagyban függ a megvilágítási körülményektől (nem megfelelő fényviszonyok között pontatlanabb, nehezebb a szemgolyó észlelése).

A természetes fénytartomány használata passzív megközelítés, ami a környezeti ambiens, azaz háttérvilágítás szemgolyóról való visszatükröződését használja ki. Az infravörös fényforrás használatával viszont a szemgolyó egyenletesen lesz megvilágítva, miközben a közeli infravörös tartományba eső fény nem zavarja a felhasználót a látásban, mivel az a vizuálisan nem érzékelhető. Ennek köszönhető, hogy a mai tekintetkövető eszközök leginkább infravörös fényforrás segítségével müködnek.

A 80-as évektől egyre könnyebbé és kisebbé váltak a kereskedelmi forgalomban kapható videokamerák, ami az informatika fejlődésével együtt biztosította a fej természetes mozgatásának a lehetőségét is a vizsgálatok közben. Ez utat nyitott a mindennapi tevékenységek részletes tanulmányozásához.

A mai modern szemkamerák az alapkutatás kérdésein túl lehetővé teszik az eszköz alkalmazását a termékfejlesztés, a marketing, illetve a web- és szoftverergonómia területein is.

Szemkamerával megvizsgálhatóak a reklámokban megjelenő stimulusok és a csomagolások, hirdetések minősége. Így optimalizálható a csomagolásokon, hirdetésekben vagy reklámokban megjelenő elemek elhelyezése annak érdekében, hogy azok minél hatékonyabban keltsék fel a vásárlók érdeklő- 
dését. A mobil szemkamera egyedi megoldásként szolgál az in-store marketing területén belül, segítségével feltérképezhető a bejárt útvonal és mérhető a polcokon elhelyezett termékek figyelemfelkeltő képessége. Webes felületek esetén (hasonlóan a szoftverekhez) a szemkamerás használhatósági értékelés célja, hogy megfigyeléseken keresztül tárja fel a termék hibáit és a lehetséges termékfejlesztési célterületeket.

A szemmozgás-követéses technológia alkalmazásának tehát számtalan lehetősége van - az eddig felsorolt területeken kívül - ma már igen sok speciális szektorban van gyakorlati jelentősége (1. táblázat).

\begin{tabular}{|c|c|}
\hline Terület & Vizsgálati lehetőségek \\
\hline Alapkutatás & $\begin{array}{l}\text { A látás és az agy alapvető kognitív mecha- } \\
\text { nizmusainak megismerése, az írás és olva- } \\
\text { sás megértése (Liversedge és Findlay 2000); } \\
\text { kommunikáció és információfeldolgozó } \\
\text { viselkedés vizsgálata (Komlodi és Hercegfi } \\
\text { 2010; Józsa és Hámornik 2012); búvárkodás, } \\
\text { repülés (Allsop és Gray 2014), vezetés (Doshi } \\
\text { és Trivedi 2009) tanulmányozása, virtuális } \\
\text { valóság kutatások (Köles és mtsai. 2014) }\end{array}$ \\
\hline Általános termékfejlesztés & $\begin{array}{c}\text { Használhatósági és prototípus tesztelés, új } \\
\text { termékvonal kialakítása, javított termék- } \\
\text { változatok létrehozása (Babicsné Horváth, } \\
\text { Hercegfi és Hidas 2018) }\end{array}$ \\
\hline Asszisztív technológiák & $\begin{array}{c}\text { Speciális felhasználók számára létrehozott } \\
\text { támogató technológiák kialakítása (Biswas } \\
\text { és Langdon 2011) }\end{array}$ \\
\hline Web-és szoftverergonómia & $\begin{array}{l}\text { Használhatósági tesztelés (Lenzner, Kacz- } \\
\text { mirek és Galesic 2014) (Goldberg és Wi- } \\
\text { chansky 2003; Tonbuloğlu 2013) }\end{array}$ \\
\hline Marketingkutatás & $\begin{array}{c}\text { Csomagolások (Hámornik és mtsai. 2013) } \\
\text { hirdetések minőségének vizsgálata (Korpás } \\
\text { és Szabó 2019), in-store kutatások speciális } \\
\text { környezetben (Koren, Lógó és Szabó 2019), } \\
\text { reklámvideók elemzése, speciális neuro- } \\
\text { marketing kutatások }\end{array}$ \\
\hline
\end{tabular}

1. táblázat: A szemmozgás-követéses technológia alkalmazási lehetőségei

\section{A szemmozgáskövetés müködésének alapjai}

A szem a látás érzékszerve, amely - a kamerához hasonlóan - a környezeti objektumokról származó (az azokból eredő vagy róluk visszaverődő) fénysugarak érzékelésére szolgál, és optikai rendszerével leképezi azok alakját, 
térbeli helyzetét és színét. Ez a kép idegi ingerületek formájában kerül továbbításra a központi idegrendszerbe, ahol a feldolgozás után szükség szerint tudatosul. Az embernél a látás a külvilágról való tájékozódásban és az ahhoz való alkalmazkodásban alapvető szerepet játszik. A látás tehát a vizuális információk gyűjtésének folyamata. A külvilágból érkező információk körülbelül 80\%-át a szemünkön keresztül érzékeljük (Haupt és Huber 2008).

A szemmozgásoknak sokféle típusa különböztethető meg egymástól, amelyek közül szemmozgás-követéses technológia módszerek szempontjából a legfontosabbak a fixációk és a szakkádok (2. ábra). A fixációk tipikusan 200-600 ms hosszúságú szemmozgások, amelyek során a tényleges információfelvétel és a vizuális bemeneti ingerek kognitív feldolgozása történik. A szakkádok pedig az ezeket összekötő gyors, ballisztikus szemmozgástípusok, amelyek lehetővé teszik a perifériáról a foveára történő váltást. A szakkádikus szemmozgások alatt a vizuális rendszer nem vesz fel új információt (szakkádikus elnyomás jelensége). A szakkádikus elnyomás aktív idegi folyamat, amely folyamán a fixációk során szerzett információkkal az agynak bonyolult számításokat kell elvégeznie ahhoz, hogy az észlelt információkat egész képpé rakja össze (Sekuler és Randolph 2006).

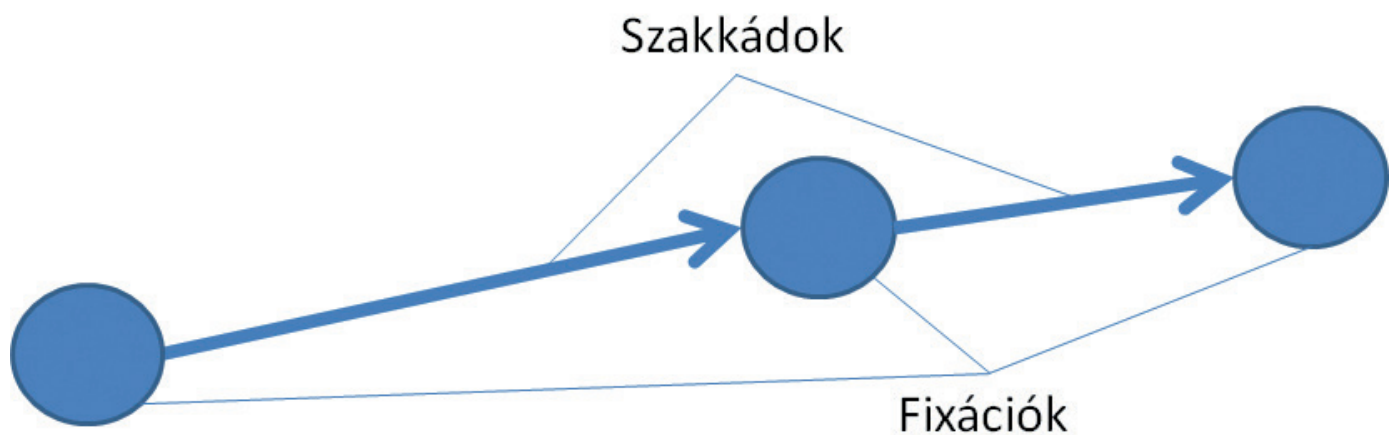

2. ábra: Fixációk és szakkádok

A szemkamera egy olyan berendezés, amely közel-infravörös megvilágítás és optikai szenzorok segítségével gyüjt adatokat a tekintet irányáról és a szemmozgásáról nagyon nagy pontossággal. A legtöbb szemmozgáskövető berendezés a szaruhártya (cornea) tükröződés technikáját alkalmazza. A szemkamerák használata során a mikroprojektorok visszatükröződéseket hoznak létre a szemekről, amelyeket a felhasználó és a szemek képével együtt optikai szenzorok regisztrálnak valós időben. Képfeldolgozó algoritmusok segítségével a rendszer megállapítja a felhasználó, a szemek és a tükröződés jellemző jegyeit, miközben a szemek pontos helyzete és a tekintet iránya matematikai modellek alapján kerül kiszámolásra (3. ábra). 


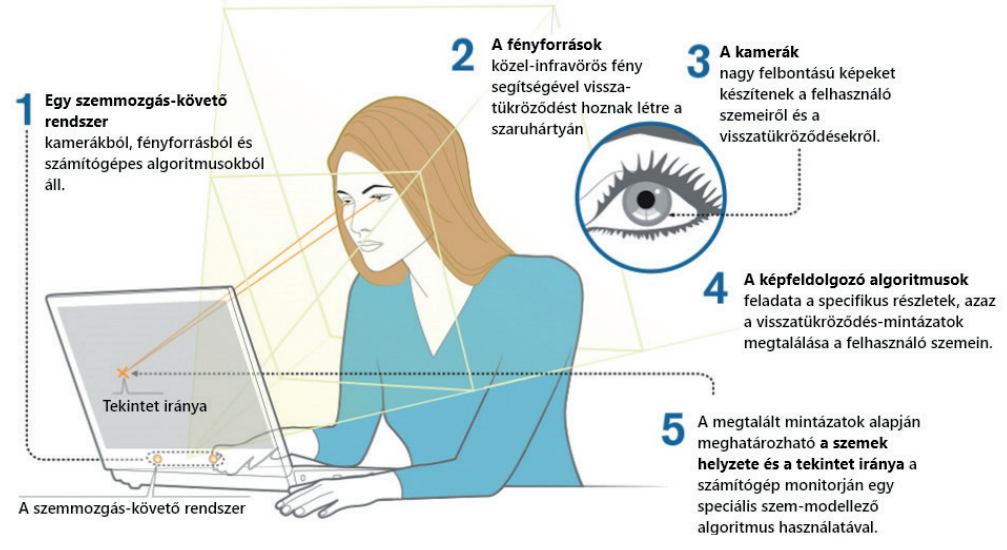

3. ábra: A szemmozgáskövető rendszer müködése (Tobii 2019)

\section{Kiértékelési lehetőségek}

A különféle ember-számítógép interakciós vizsgálatok során a szemmozgás-követéses eszközök segítségével pontosan rögzíthető tehát a tekintet iránya, amelyből megállapítható például, hogy hol történt fixáció, és azok milyen hosszú ideig tartottak.

Igény szerint meghatározhatók továbbá akár a fixációk közötti szakkád amplitúdók és szakkád sebességek is, amelyek a végrehajtott feladatok nehézségéről adhatnak információt - nehezebb feladatok esetén általában például a gyorsabb szakkádok mérhetők.

A szemmozgáskövető rendszerekből kinyerhető adatok közös jellemzők alapján oszthatók mozgási (movement), elhelyezkedési (position), mennyiségi (numerosity), késleltetési és távolsági (latency and distance) csoportokba (Holmqvist et al. 2011).

\section{1. csoport: Mozgási mutatók}

A szemkamerás mérések során a rendszer a szem mozgásának jellemző tulajdonságait használja. Ilyenek az irány, az amplitúdó, a hossz, a sebesség és a gyorsulás. E mutatók segítségével meghatározható, hogy a szem milyen irányba és milyen messzire jutott el, mennyi ideig mozgott, mekkora sebességgel és gyorsulással, valamint összehasonlíthatóvá válnak a bejárt útvonalak.

2. csoport: Elhelyezkedési mutatók

Az elhelyezkedési mutatók a nézés pozíciójához köthetők, így olyan estekre és annak különböző tulajdonságaira vonatkoznak, amikor a kísérleti személyek egy adott helyre fókuszáltak. A pozíciós adatok a fixációk pontos helyéhez, szóródásához, hasonlóságához, hosszához és a pupilla méretének átmérőjéhez köthető mutatókat határoznak meg. 


\section{3. csoport: Mennyiségi mutatók}

A szemkamerás mérések során rendelkezésünkre álló pillanatnyi adatok számszerüsítésére a legegyszerübb módszer a kísérlet szempontjából releváns mutatók összeszámolása. Az így rendelkezésre álló mennyiségi mutatók megadják a leszámolható entitások számát, arányát, frekvenciáját. Ilyenek lehetnek például a szakkádok és fixációk darabszáma, a különböző érdeklődési területen eltöltött összes tartózkodási idő, vagy hogy egy-egy terület pontosan hányszor vonzotta vissza a kísérleti személy figyelmét. Ebbe a kategóriába tartozik a pislogási ráta, amely összefüggésben áll a figyelemmel (minél magasabb az értéke, annál kevésbé köti le a résztvevőt az adott feladat).

\section{4. csoport: Késleltetési és távolsági mutatók}

A szemmozgások tekintetében a késleltetési és távolsági mutatók is releváns információkat adhatnak meg. A késleltetési mutatók segítségével meghatározható például, hogy egy adott ingeranyag megjelenéséhez képest mennyivel később történik szemmozgás, vagy kezd el változni a pupilla mérete. A távolsági mutatók pedig megadják például a bal és a jobb szem közötti fixációs pontok különbségét, vagy az egérhez viszonyított távolságát.

A piacon elérhető asztali szemkamerák tipikusan 60 és $1200 \mathrm{~Hz}$ közötti mintavételi frekvenciával müködnek, ami azt jelenti, hogy használatuk esetén már egy-egy rövidebb vizsgálat során is kvantitatív adatok állnak rendelkezésre nagy mennyiségben a feladatmegoldásokkal kapcsolatban. Ezek az információk statisztikai elemzések után lehetővé teszik a vizuális csatornán keresztül észlelt ingerek megértését.

\section{1. Érdeklődési területek kijelölése}

A szemkamerás szoftverek lehetővé teszik a különböző érdeklődési (Area Of Interest) területek manuális vagy automatikus kijelölését (klaszterképzés). A felhasználó által definiált, kézzel kijelölt AOI részek lehetővé teszik a kutatók által kiemelt fontosságúnak gondolt területek további vizsgálatát, segítségükkel meghatározható, hogy a kísérleti alanyok pontosan hova néztek ezeken a területeken belül, és mennyi ideig, illetve, hogy a tekintetük hányszor is tért vissza ugyanoda.

Az AOI elemzések során használt mutatók közül éppen ezért a fixációk hossza és darabszáma, valamint a látogatások (területre történő visszatérések) száma elnevezésű mutatók a leggyakrabban használtak, mivel azok az adott területek szubjektív fontosságát jelzik (Hámornik és mtsai. 2013).

\subsection{Vizualizációk}

A szemmozgás-követéses adatok nemcsak számszerüen állnak a kutatók rendelkezésére, hanem vizuálisan is megjeleníthetők (Duchowski 2007). A leggya- 
koribb ábrázolási forma az úgynevezett „heatmap” (hőtérkép) névre hallgató vizualizáció, amikor az összes felhasználói adat aggregált módon jelenik meg a vizsgált ingeranyagon - a legtöbbet nézett pontok (ahova a leghosszabb fixációk estek összességében) meleg (vörössel), a kevesebbet nézett területek pedig hidegebb (zöld) színnel jelennek meg.

Másik gyakori megjelenítés az úgynevezett „scan path” ábrázolás. Ekkor az ábrán a szakkádokat vékony vonalak jelzik, a fixációk pedig számozva (ezzel a sorrendiséget jelölve), különböző nagyságú körök formájában jelennek meg (hosszabb fixációhoz nagyobb átmérőjű kör tartozik). Így ez az ábra részletesen megmutatja, hogy a kísérleti személyek tekintete milyen sorrendben járta be az ingeranyagot (a különböző színek különböző felhasználókat jelölnek) (Szabó és Szederkényi 2020, 74).

\section{Esettanulmányok}

A használhatósági értékelés a termék tesztelését jelenti a valós, vagy potenciális fogyasztók körében. A módszer így vizsgálja, hogy a termék mennyire használható a céljára, valamint a különböző termékfunkciók teljesülését vagy éppen a teljesülésük hiányát méri (Rogers, Sharp és Preece 2011).

A feladatorientált használhatósági vizsgálat differenciált képet ad arról, hogy a különböző szintű termékhasználati tapasztalattal rendelkező (célcsoportba tartozó) felhasználók mennyire sikeres interakciókra képesek a termékkel. A vizsgálat során nyert információk (például végrehajtási idők és érzelmi reakciók) összességéből képezhetők olyan mutatók, amely mentén termékszinten elemezhetők és összehasonlíthatók az interakciók során nyújtott egyéni és csoportos teljesítmények és ráfordítások (Antalovits és Süle 2012,114).

A használhatósági vizsgálatok során a hangos gondolkodás (úgynevezett „think aloud” protokoll) módszerének alkalmazása az, ami segít explicitté tenni, hogy az interakciók során mi történik a felhasználó fejében (Dumas és Loring 2008), így az a participatív fejlesztés igen hasznos eszköze lehet. A szemmozgáskövetés technológiájának használata mint kiegészítő pszichofiziológiai mérés pedig többletinformációkat ad a tevékenységek végrehajtásakor használt vizuális figyelem mintáiról.

Webes felületek (vagy szoftverek) használhatósága esetén a szemkamera alkalmazásának a célja, hogy további vizuális megfigyeléseken keresztül tárja fel a termék hibáit és a lehetséges termékfejlesztési célterületeket (Goldberg és Wichansky 2003).

\subsection{Fakopáncs webáruház vizsgálata}

A Fakopáncs '92 Kft. webáruházán elvégzett szemkamerás használhatósági vizsgálat során a felhasználók a folytonos hangos gondolkodás (Concurrent 
Think-Aloud, továbbiakban CTA) módszerét alkalmazták, így a gondolataikat a feladatok végrehajtása közben, azokkal párhuzamosan verbalizálták (Cooke 2010).

A használhatósági vizsgálat kilenc feladatból állt, amelyek az oldalon végezhető legjellemzőbb tevékenységek alapján kerültek összeállításra, így azok a regisztráció menetének, a profiladatok (például jelszó) módosíthatóságának, a menürendszer felépítésének, valamint az online vásárlási folyamat véglegesítési lépéseinek ésszerüségét vizsgálták.

Ahhoz, hogy egy használhatósági vizsgálat adekvát eredményeket adjon, fontos, hogy az abban résztvevők a termékhasználat szempontjából releváns célcsoportba tartozzanak (Rubin, Chisnell és Spool 2008). Mivel a cég által használt Google Analytics mérőkód részletes információkat nyújtott a felhasználókról, így lehetővé tették a megfelelő kísérleti személyek kiválasztását. A használhatósági vizsgálatban éppen ezért többségében nők vettek részt, az életkort tekintve pedig a 22-45 éves életkori tartomány dominált (2. táblázat).

Nielsen (2000) szerint a használhatósági vizsgálatokba 5 főt érdemes bevonni, hiszen ez már egy olyan létszám, ahol kvalitatív módon a használhatósági hibák 80\%-a feltárható. A használhatósági vizsgálatok összeállítása során oda kell figyelni a gondos előkészítésre, mely a felhasználói csoport(ok) meghatározásával kezdődik. A kutatási kérdéstől függően külön fontos lehet az adott termék vonatkozásában gyakorlatlan (laikus) és tapasztalattal rendelkező felhasználók viselkedése is. Bizonyos esetekben pedig mindkét csoport eredményei fontosak a termékfejlesztés szempontjából.

Ebben az esetben a vizsgálati személyek két csoportba kerültek. Az egyik csoport tagjai (3 fö) olyan tapasztalt vizsgálati célszemélyek voltak, akik támogatják az interneten történő vásárlást, és gyakran élnek az e-kereskedelem nyújtotta lehetőségekkel. A másik csoport tagjai (3 fő) olyan internethasználók közül kerültek kiválasztásra, akik ritkán vásárolnak online módon (a különböző vásárlói felületeket korábban inkább informálódás céljából használták), így laikus felhasználóknak tekinthetők (2. táblázat).

\begin{tabular}{|c|c|c|c|}
\hline Azonosító & Kor & Nem & TCT [perc:mp] \\
\hline Tapasztalt_1 & 25 & Nő & $20: 33$ \\
\hline Tapasztalt_2 & 26 & Férfi & $28: 05$ \\
\hline Tapasztalt_3 & 27 & Nő & $18: 40$ \\
\hline Laikus_1 & 57 & Nő & $31: 42$ \\
\hline Laikus_2 & 58 & Férfi & $42: 42$ \\
\hline Laikus_3 & 37 & Nő & $26: 14$ \\
\hline
\end{tabular}

2. táblázat: A feladatmegoldási idők (TCT) alakulása a résztvevők körében 
A feladatvégrehajtási idő (Task Completion Time) egy olyan ráfordítási mutató, amely a termék használhatóságát jellemzi, így gyakran alkalmazzák a használhatósági vizsgálatok eredményeinek értelmezése során (Antalovits és Süle 2012, 121).

A 2. táblázatból látható, hogy a két csoport között jelentős különbség keletkezett a feladatsor megoldásának az időtartamában. A laikus felhasználók körében a lassabb feladatmegoldás a tapasztalat hiányra vezethető vissza. Általában több időbe telt a feladatok végrehajtásához nélkülözhetetlen operátorok (gombok, ikonok) megtalálása, illetve az egyujjas gépelés is jelentősen lassította a részfeladatok megoldási idejét (kivéve a nem egy ujjal gépelő Laikus_3 felhasználó esetén).

Az első feladat „TESZT” vezetéknévvel és egyéb tetszőleges adatok megadásával a regisztráció végrehajtására kérte a felhasználókat. Mivel a webáruház oldalán a regisztrációs lehetőség nincs kiemelve, így a felhasználók meglehetősen sok időt töltöttek el annak a felkutatásával (3. táblázat). Az adatokból jól látható, hogy az AOI területként kijelölt „Regisztráció” gombra történő kattintásig átlagosan 24,12 (extrém esetben 65,51) másodperc telt el 24,13-as szórás értékkel, valamint az egyéb szemmozgás-követéses mutatók számszerűen is igazolják azt, hogy ez a lehetőség az oldalon valóban nehezen lelhető fel (a kattintásig eltelt idő alatt tipikusan csak néhány és igen rövid ideig tartó fixáció esett erre a részre). Ezt a problémát a résztvevők az utólagos interjú során kivétel nélkül mindannyian megemlítették mint a feladatmegoldást egyértelműen nehezítő tényezőt.

\begin{tabular}{|c|c|c|c|c|c|}
\hline Azonosító & $\begin{array}{c}\text { Első } \\
\text { fixációig } \\
\text { eltelt idő } \\
\text { [mp] }\end{array}$ & $\begin{array}{c}\text { Első fixáció } \\
\text { hossza [mp] }\end{array}$ & $\begin{array}{c}\text { Összes } \\
\text { fixáció } \\
\text { időtartama } \\
\text { [mp] }\end{array}$ & $\begin{array}{c}\text { Fixációk } \\
\text { száma [db] }\end{array}$ & $\begin{array}{c}\text { Kattintásig } \\
\text { eltelt idő } \\
\text { [mp] }\end{array}$ \\
\hline Tapasztalt_1 & 14,39 & 0,27 & 1,92 & 2 & 15,23 \\
\hline Tapasztalt_2 & 7,69 & 1,23 & 2,97 & 2 & 9,04 \\
\hline Tapasztalt_3 & 0,91 & 0,07 & 0,39 & 3 & 6,52 \\
\hline Laikus_1 & N/A & N/A & N/A & N/A & N/A \\
\hline Laikus_2 & 8,02 & 0,04 & 4,95 & 12 & 24,31 \\
\hline Laikus_3 & 4,47 & 0,15 & 1,95 & 4 & 65,51 \\
\hline
\end{tabular}

3. táblázat: A regisztrációs területre lekért AOI adatok

A sikeres regisztráció után a használhatósági vizsgálat résztvevőinek meg kellett változtatniuk az általuk megadott jelszót. A feladatmegoldás során a felhasználók a „Jelszó” és a „Jelszó ellenőrzése” mezők kitöltése után helyesen az oldal alján található „Mentés” gombra kattintottak. A hat résztvevőből 
négyen ezt a folyamatot azonban többször is megismételték, mivel nem vették észre az oldal arculatába beolvadó zöld színű információs sávot középen, amely a sikeres adatmódosítást jelezte. Ezt támasztja alá a feladatmegoldás során keletkező hőtérképes vizualizáció, amely a vizsgálatban résztvevő hat kísérleti személy aggregált fixációs adatait mutatja (4. ábra).

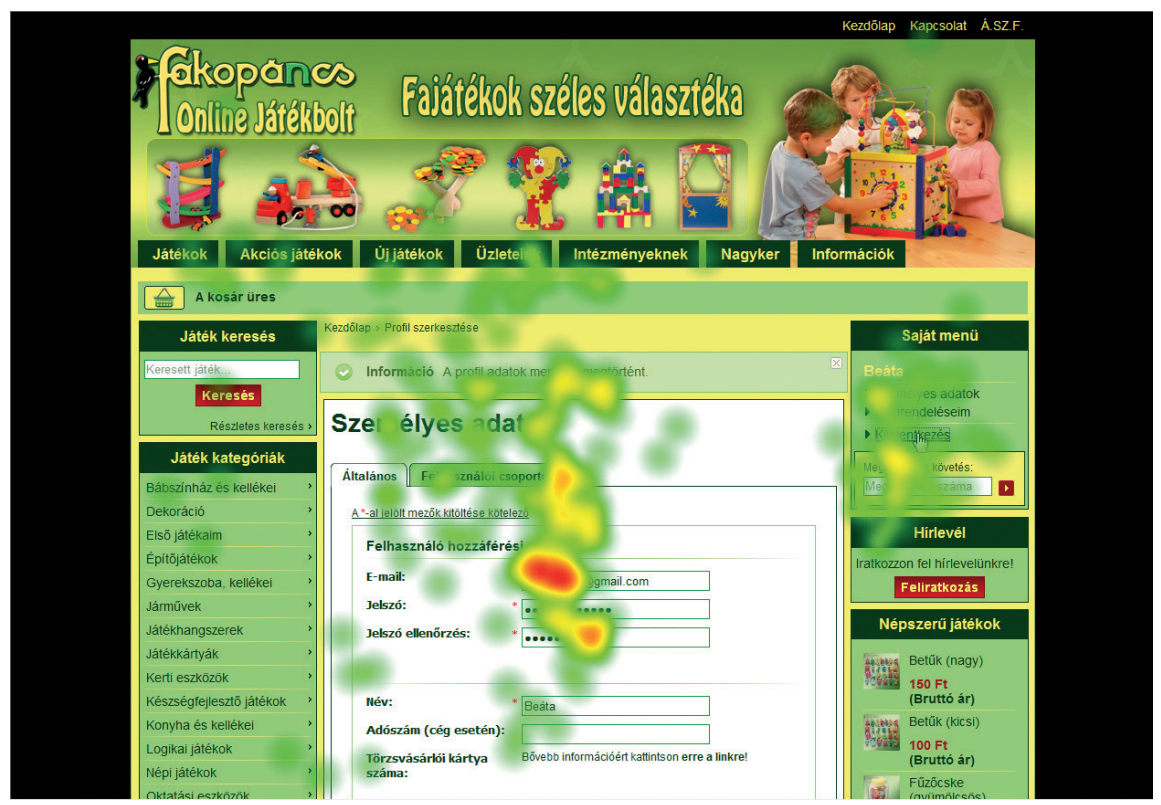

4. ábra: Hőtérkép a sikeres adatmódosítást visszajelző üzenet észrevehetetlenségéről

Ezek után a résztvevőknek négy előre megadott játéktípust (logikai játék, pajzs, szövőkeret, ceruza) kellett a kosárba helyezniük, amely során nem használhatták az oldal tetején található keresőt, hiszen ez a feladatrész a bal oldali menürendszer átláthatóságát, logikus felépítését vizsgálta. A négy termék kosárba tételéhez átlagosan 3 perc 41 másodpercre volt szükség (1 perc 47 másodperces szórással), a feladatmegoldás során a hangos gondolkodás segítségével kiderült az is, hogy a második vagy a harmadik szintủ alkategóriák elnevezése sokszor nem logikus, az ott elhelyezkedő termékek megtalálása így gyakran okozott bosszúságot.

A feladat jellegét tekintve nem meglepő, hogy a bal oldali „Játék kategóriák” elnevezésű vertikális menü, valamint az abból nyíló alkategóriák voltak azok a területek, ahova a feladatmegoldás során a legtöbb fixáció esett, illetve a „Termék kosárba került” feliratú modális ablak „Vásárlás folytatása” gombja kapott még kiemelt figyelmet középen (5. ábra). A hőtérkép ebben az esetben azonban további termékfejlesztési területre is felhívja a figyelmet, hiszen jól láthatóan mutatja, hogy a 9000 forint fölötti kosárérték esetén megjelenő, a szállítási díj megváltozását jelző figyelmeztető üzenetet a felhasználók egyáltalán nem vették észre. 


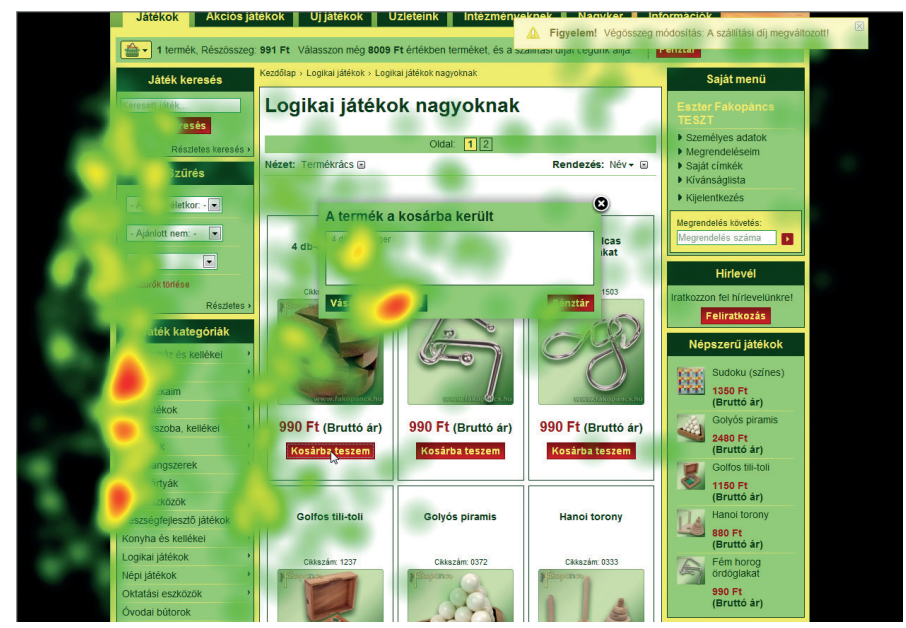

5. ábra: Hőtérkép a szállítási díj megváltozására figyelmeztető üzenet észrevehetetlenségéről

A termékek kosárba helyezése után véglegesíteni kellett a megrendelést úgy, hogy a rendszer jelezze a futárnak, hogy a megrendelő nagy címlettel fog fizetni. A véglegesítési folyamat során a megadott szállítási és fizetési mód kiválasztása nem okozott problémát, azonban az „Áttekintés és megrendelés” résznél a felhasználók minden esetben rosszul oldották meg a feladatot, mivel a felső megjegyzésdobozba írták, hogy 20 000-es címlettel kívánnak fizetni. Az oldalon a felső megjegyzés a webáruház ügyfélszolgálatának szól, az alsó pedig a csomagküldő szolgálatnak, de mivel a két doboz nem egyforma méretü, így a nagyobb jobban vonzza a felhasználók tekintetét. Ezt támasztja alá az egy felhasználó szemmozgásait mutató scan path vizualizáció, ami minden esetben hasonlóan alakult (6. ábra).
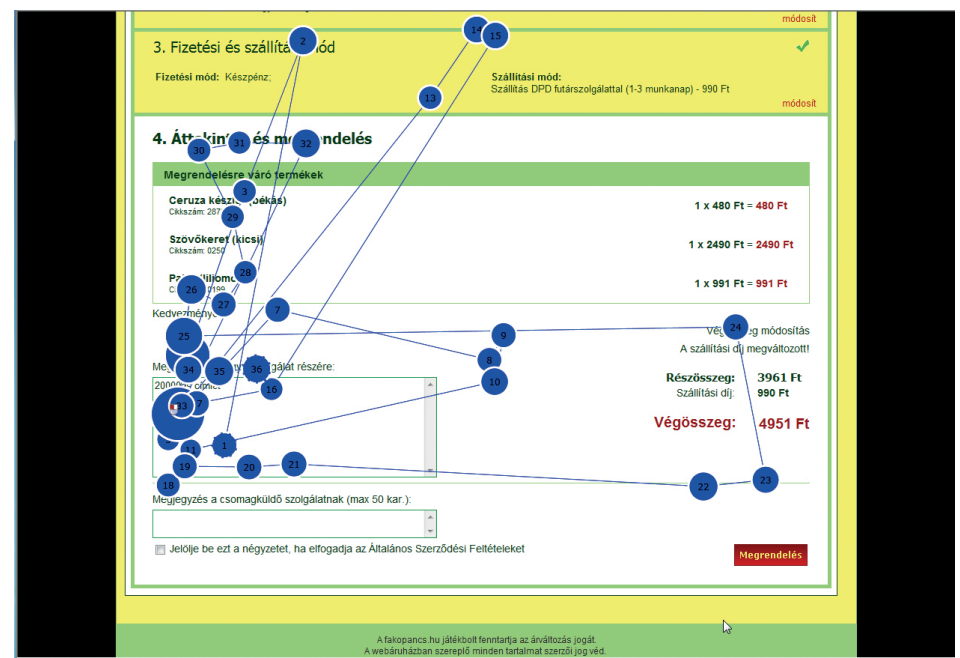

6. ábra: Scan path vizualizáció a megrendelési folyamat véglegesítéséről

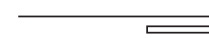




\subsection{ChocoMe webáruház vizsgálata}

A ChocoMe Kft. webáruházával kapcsolatos használhatósági vizsgálat az előző esettanulmányhoz hasonlóan szintén a hangos gondolkodás módszerének alkalmazásával került megvalósításra, itt azonban nem a folytonos (CTA) metódus került alkalmazásra, hanem az visszatekintő (retrospective, továbbiakban RTA) változat (Haak és Jong 2003).

Az RTA módszer során a kísérleti személy a feladatmegoldás közben keletkező videofelvétel mint vizuális emlékeztető segítségével utólag (retrospektív módon) értékeli a látottakat. A vizsgálat során tehát egyfajta önmegfigyelés megy végbe, amikor a résztvevő gondolataira és következtetéseire támaszkodva elemzi a megélt tapasztalatait és érzelmeit (Alshammari, Alhadreti és Mayhew 2015).

A kísérleti személyek laikus és tapasztalt bontásban ebben az esetben is a Google Analytics felületéről kinyert adatok alapján kerültek toborzásra az előző esettanulmányhoz hasonlóan. Mivel a vizsgált oldalt 62\%-ban nők használják, így a résztvevők között ebben az esetben is a nők voltak többségben. Az adatokból látható volt, hogy a weboldalt a közel 50\%-ban a 25-34 év közötti korosztály használja, ennek megfelelően a kísérleti személyek fele ebből a korcsoportból került kiválasztásra. További egy kísérleti személy a 18 és 24 év közötti korosztályt képviseli, kettő pedig a 35 és 44 év közötti, ezzel a legjobban megközelítve a Google Analytics szolgáltatása által generált éltkori elosztást bemutató kördiagramot.

A konkrét használhatósági vizsgálat hét feladatból épült fel, amelyek a Google Analytics felületéből kinyert adatok alapján különböző, előzetesen azonosított konverziós céloknak megfelelően került összeállításra. A feladatsor ebben az esetben így a keresőszavak optimalizálását, a hírlevél feliratkozás menetének meglétét is vizsgálata a vásárlási folyamat megfelelősége mellett.

A feladatsor megoldása átlagosan 20 perc 7 másodpercet vett igénybe (7 perc 34 másodperces szórással), itt azonban a feladatvégrehajtási idő (TCT) mellett további, a használhatóságot szintén jól tükröző mutatók is értékelésre kerültek. A sikerességi mutató a feladatrészek végrehajtásának a sikerességét méri, az érzelmi ráfordítási mutató pedig a felhasználók érzelmi reakcióit számszerüsíti (Antalovits és Süle 2012, 121).

A sikeresség a termék-felhasználó interakció eredményességi jellemzőjének tekinthető, amely egy négyfokozatú skálán értékelhető. Az egyes horgonypontok a 0,1, 2 és 3 skálaértékeket vehetik fel, ahol az egyes értékek az alábbi jelentésekkel bírhatnak weboldalak vizsgálata esetén:

- „0”: Nem oldotta meg a feladatot (elkezdte ugyan, de feladta a feladat megoldását)

- „1”: Megoldotta a feladatot jelentősebb mértékủ segítség igénybevételével (nagyobb mértékủ moderátori támogatásra szorult)

- „2”: Megoldotta a feladatot csekély mértékű segítség igénybevételével (kisebb moderátori megerősítésre volt szüksége) 
- „3”: Teljesen önállóan hajtotta végre a feladatot, a feladatsoron kívül semmilyen más támogatást nem igényelt a feladat megoldásához

Ezenkívül a feladatmegoldások során az egyes műveletek olyan érzelmi reakciót váltanak ki a felhasználókból, amelyek szintén egyértelműen megfigyelhetők, értelmezhetők és egy skálán értékelhetők (Antalovits és Süle 2012,121). Az érzelmi ráfordítási skála az alábbi horgonypontok mentén értelmezhető:

- „-1” = Sikerélmény (a feladat pozitív élményt váltott ki a felhasználóból)

- „0” = Közömbösség (a feladat nem váltott ki érzelmi reakciót a felhasználóból)

- „1” = Bosszankodás (a feladat negatív érzelmet, kis mértékű frusztrációt váltott ki a felhasználóból)

- „3” = Dühkitörés (a feladat negatív érzelmet, nagy mértékű frusztrációt, vagy azt elfojtva teljes leblokkolást váltott ki a felhasználóból)

Ezekből a skálaértékekből meghatározhatók a vizsgálati személyek teljes csoportjának az átlagos sikerességi és érzelmi ráfordítási mutatói, amelyek a használhatóságot jól jellemzik és kijelölik azokat a feladatrészeket, ahol problémák léptek fel (4. táblázat). Sikeresség esetén összesítve az alacsony, érzelmi ráfordítás esetén pedig a kiemelkedően magas értékekre érdemes odafigyelni.

\begin{tabular}{|c|c|c|c|c|c|c|c|c|c|c|c|c|c|c|}
\hline $\begin{array}{c}\text { Feladat } \\
\text { sorszáma }\end{array}$ & $\mathbf{1}$ & $\mathbf{2}$ & $\mathbf{3}$ & $\mathbf{4}$ & $\mathbf{7}$ & $\mathbf{6}$ & $\mathbf{7}$ & $\mathbf{1}$ & $\mathbf{2}$ & $\mathbf{3}$ & $\mathbf{4}$ & $\mathbf{5 .}$ & $\mathbf{6 .}$ & 7. \\
\hline & \multicolumn{10}{|c|}{ Érzelmi ráfordítás } \\
\hline Résztvevő_1 & 3 & 0 & 0 & 3 & 1 & 2 & 2 & -1 & 1 & 1 & 1 & -1 & -1 & -1 \\
\hline Résztvevő_2 & 3 & 0 & 0 & 3 & 1 & 2 & 0 & -1 & 1 & 1 & 1 & 1 & -1 & 1 \\
\hline Résztvevő_3 & 3 & 2 & 0 & 3 & 2 & 1 & 0 & 0 & 1 & 0 & 0 & 1 & 0 & 1 \\
\hline Résztvevő_4 & 3 & 3 & 3 & 3 & 2 & 3 & 2 & 0 & 1 & 1 & 0 & 1 & 0 & 1 \\
\hline Résztvevő_5 & 3 & 1 & 1 & 3 & 1 & 1 & 0 & -1 & 1 & 1 & 1 & 1 & 0 & 1 \\
\hline Résztvevő_6 & 3 & 2 & 2 & 3 & 3 & 3 & 2 & 0 & 1 & 1 & 0 & 1 & 0 & 1 \\
\hline &
\end{tabular}

4. táblázat: A feladatmegoldás során keletkező sikerességi és érzelmi ráfordítási értékek

Az első feladat során a felhasználóknak az oldal nyelvét kellett angolra állítaniuk, amellyel semmilyen nehézségük nem adódott.

A második, információkeresési feladat azonban már ennél jóval megosztóbb volt. Itt a retrospektív hangos gondolkodás során a résztvevők többségének az volt az észrevétele a felülettel kapcsolatban, hogy az olvashatóság és a 
láthatóság nem ideális, túlságosan vékony és kisméretű az oldal által használt betütípus. Mindemellett kifejezetten előnytelennek tartották azt is, hogy a feladat során keresett és amúgy is fontosnak tartott, nyitvatartási információ az oldal legalján volt megtalálható.

A keresési feladat második részének a megoldása (külföldi értékesítőhelyek megtalálása) extrém módon sok időt vett igénybe. Itt a feladatmegoldás nehézségei abból fakadtak, hogy a „Kapcsolat” menüpont alatt megjelenő „Sajtóközlemények”, „chocoMe értékesítőhelyek”, „chocoMe international” feliratú almenük nem voltak észlelhetők és azok elnevezése sem volt megfelelő. Éppen ezért a felhasználók először végiggörgettek az oldalon, és csak utána vették észre ezt a három további, kattintható lehetőséget. A résztvevő itt már egyértelműen azt gondoltak, hogy a középső „chocoMe értékesítőhelyek” felirat alatt találják majd a szükséges információkat, miközben ott csak a magyar viszonteladó hálózat partnereinek elérhetősége szerepelt. Ez módszertanilag az almenük mint AOI területek kijelölésével (7. ábra) számszerűen is alátámasztható.

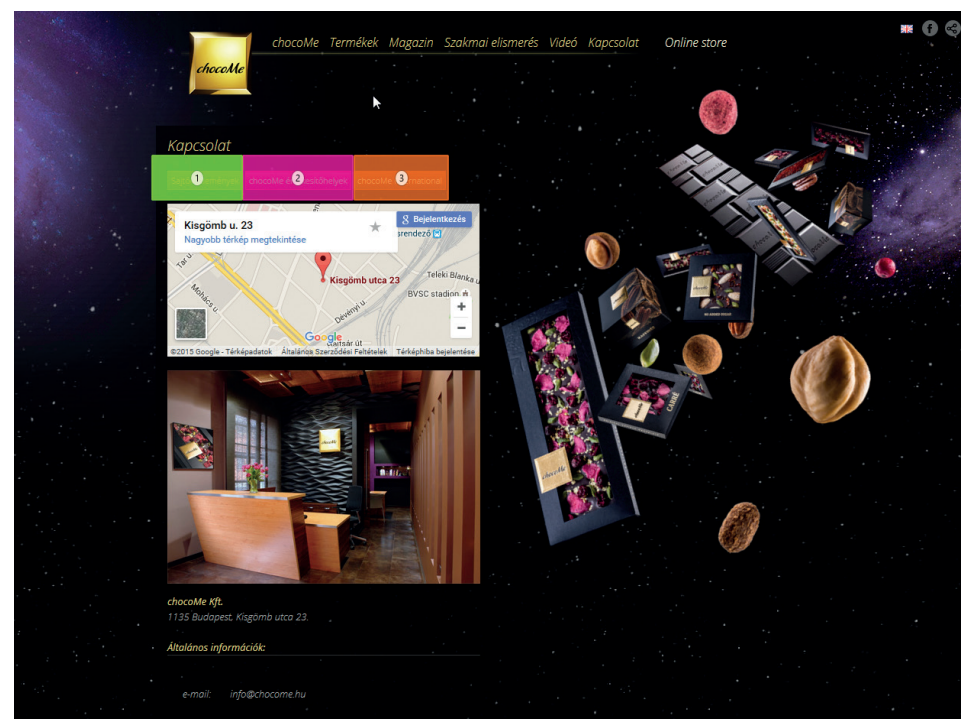

7. ábra: A „Kapcsolat” almenük kijelölése AOI területekként

Az AOI területeken keletkező fixációs adatokból jól látható, hogy az 1-es (zöld) és a 2-es (lila) területre a felhasználók mindegyike ránézett, míg a 3-as (narancsszínű) érdeklődési területre csupán a felhasználók fele (5. táblázat).

A fixációs darabszámok közötti különbség a kis elemszámból adódóan statisztikailag Mann-Whitney próbával vizsgálható. Az adatok az 1-es és 2-es, illetve az 1-es és 3-as területetek között nem mutatnak szignifikáns különbséget, azonban második és harmadik oszlop között már tendenciózus eltérés adódik (U=6,5; Z=-1909; p=0,056). Ez a különbség a résztvevők számának a növelésével feltehetően már szignifikáns lenne, ami így már statisztika eszközével is igazolná, hogy a feladatmegoldás közben valóban a „chocoMe értékesítőhe- 
lyek” menüpont kapta a legtöbb figyelmet. Mivel ez volt a felhasználók számára a legfontosabb rész, és itt nem találhatók meg a keresett információk, így érdemes lenne a vállalatnak megfontolnia az almenüfeliratok átnevezését, vagy az aloldalakon megjelenő információk átsrukturálását.

\begin{tabular}{|c|c|c|c|}
\hline & \multicolumn{3}{|c|}{ Fixációk darabszáma } \\
\hline & 1-es AOI & 2-es AOI & 3-as AOI \\
\hline Résztvevő_1 & 1 & 3 & 2 \\
\hline Résztvevő_2 & 7 & 2 & 1 \\
\hline Résztvevő_3 & 0 & 2 & 0 \\
\hline Résztvevő_4 & 3 & 5 & 0 \\
\hline Résztvevő_5 & 1 & 8 & 2 \\
\hline Résztvevő_6 & 0 & 0 & 0 \\
\hline \multicolumn{2}{|c|}{12} & 20 & 5 \\
\hline Összesen & \multicolumn{2}{|c|}{} \\
\hline
\end{tabular}

5. táblázat: Az AOI területekre lekért fixációs darabszámok

Az egyik legnagyobb kihívást a keresőszavakkal kapcsolatos (harmadik) feladat jelentette a kísérletben résztvevők számára, amely során a korábban megismert weboldalra a Google keresőjéből kellett elnavigálniuk szabadon választott keresőszavak segítségével.

A feladatmegoldás sok esetben sikertelenül zárult, mivel a felhasználók nagy része az általuk használt keresőszavak beírása nem találták a webáruházat a Google organikus keresési találatai között, amelyek alátámasztják a keresőoptimalizálás szükségességét.

A keresett szókapcsolatokban a „,csokoládé”, „egyedi”, „kézműves”, „budapest”, és „magyar” kulcsszavak jelentek meg a leggyakrabban. Népszerűek voltak még a „csoki”, „manufaktúra”, „különleges”, és „webáruház” kifejezések is (8. ábra).

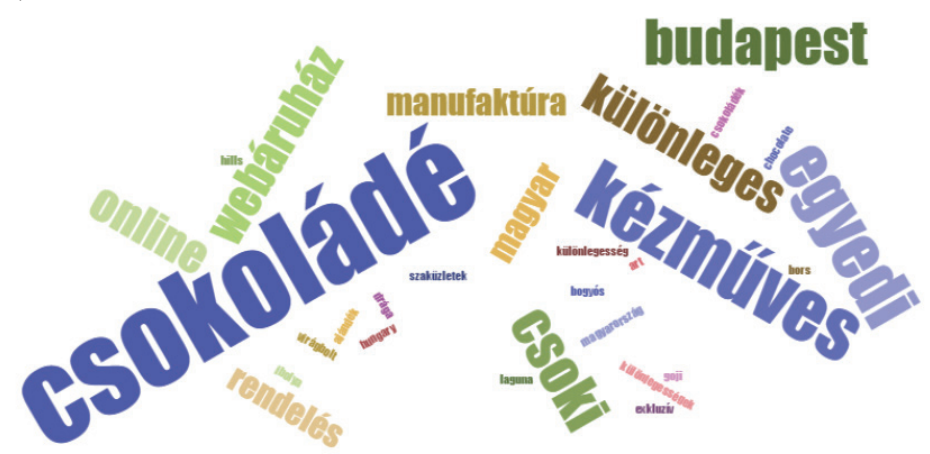

8. ábra: Szófelhő a keresett szókapcsolatokról (3. feladat) 
Az ezt követő feladat a webáruházba történő regisztráció volt, ami ugyan nagyobb sikerrel zárult, de mégis meglehetősen időigényes feladatnak bizonyult, és átlagosan 2 perc 41 másodpercet vett igénybe (1 perc 1 másodperces szórás értékkel).

A feladat végrehajtása során több résztvevőnek már a webáruház megtalálása is problémát okozott, ugyanis az a főoldal „Online store” része alatt helyezkedik el. Mivel a felhasználók nagy része a regisztráció lehetőséget közvetlenül a főoldalon kereste, így ott jóval többet időztek, mint kellett volna.

A webáruház megtalálása után további problémát okozott a „Belépés” gomb melletti regisztrációs lehetőség észrevétele. Mivel a felhasználók fejében egy olyan mentális modell élt, mely szerint ez az oldal jobb felső részében található, így először ott keresték, és csak utána vették észre, hogy a „Még nem regisztrált? Akkor itt megteheti!” üzenet az oldal bal oldalán található. A feladatsorán keletkező scan path ábra alátámasztja, hogy a megoldást nagyban nehezítette, hogy a felhasználók mentális modellje és az oldal valós müködése (fizikai modell) nem illeszkedett egymáshoz (9. ábra) (Weinschenk 2011).

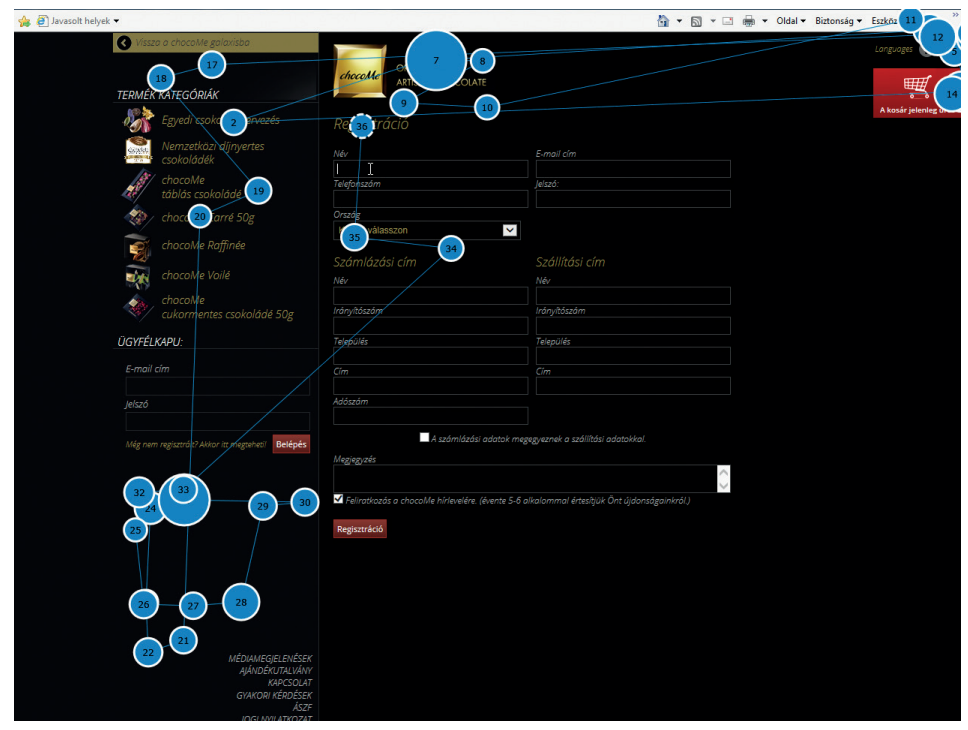

9. ábra: Scan path vizualizáció a regisztrációs felület megtalálhatóságáról

Ezt követően a fiók létrehozásához szükséges ürlap kitöltésénél is merültek fel használhatósági problémák, amelyekre a retrospektív hangos gondolkodás során fény derült.

A felhasználók megemlítették, hogy az adatbeviteli mezők esetén például nem volt egyértelműen jelölve, hogy mely mezők megadása kötelező. Problémát jelentett az is, hogy a mezők hiányos, illetve nem megfelelő formátumú kitöltése esetén a rendszer visszajelzését a kísérleti személyek nehezen vették észre, mivel ez mindösszesen egy vékony, piros színű keret formájában realizálódott az egyébként fehér adatbeviteli mezők körül. A résztvevők nehezmé- 
nyezték továbbá azt is, hogy a rendszer semmilyen magyarázatot nem adott arra vonatkozóan, hogy adott esetben miért nem megfelelő a mező(k) kitöltése, illetve mit vár el rendszer a továbblépéshez. A kísérletben résztvevők harmada hiányolta a regisztrációs mezők közül a jelszó megerősítést a véletlen elütések megelőzésére. Ez esetben azt is elvárták volna, hogy tájékoztatásban részesüljenek arról, milyen karakterekből (nagy-, illetve kisbetű, számok és/ vagy egyéb) állítsák össze az általuk kitalált jelszót.

A felhasználóknak sok esetben az országválasztó legördülő listában nem tűnt fel az se, hogy Magyarország szerepel az első választható helyen (alapbeállításként), ugyanis betürendi sorrendre számítottak.

A továbbiakban az alanyok a vásárlási folyamat lépéseit összességében egyértelműnek találták, azonban az egyedi csokoládé összeállítási funkció felkutatása a résztvevők felének nehézséget okozott (6. feladat). Ők arról számoltak be, hogy ez az egyedi csokoládé összeállítási funkció nagyon beleolvad a bal oldali menübe, holott kiemeltebb helyen számítottak rá. A már összeállított termékkreációktól és az egyes termékkategóriákból kiszakadva, szabadabban, egy külön kiemelt részt képzeltek volna el, így éreztetve a vásárlókkal, hogy ez a funkció különleges és nekik szól. Akadt, aki konkrét cselekvésre való felhívásos (Call to Action) „Tervezd meg saját egyedi csokoládédat!” feliratot is megnevezett a retrospektív rész során ennek a hangsúlyozására.

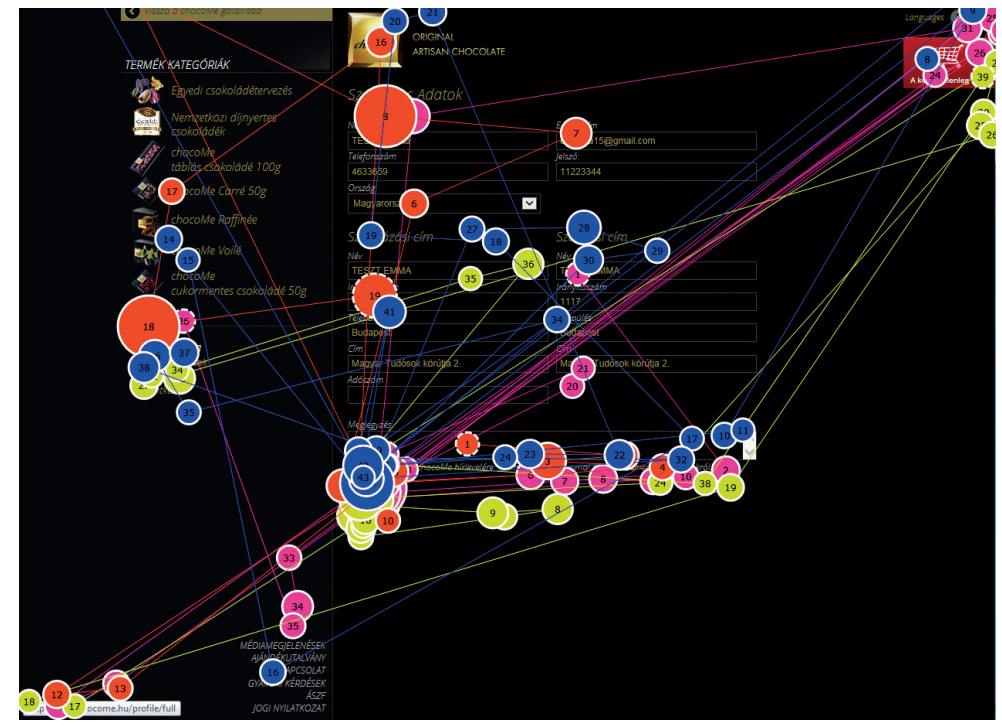

10. ábra: A hírlevél feliratkozás lehetősége során keletkező scan path vizualizáció

Az utolsó feladat a hírlevél-feliratkozás lehetőségét vizsgálta, amelyre csak regisztrációs folyamat alatt, vagy azt követően kerülhetett sor a „Személyes Adatok" módosítása során. A feladatot többen képtelenek voltak megoldani, ugyanis egyfelől ezt a lehetőséget nagyon nehezen lehetett megtalálni, másfelől ha sikerült is, a webáruház semmiféle visszajelzést nem adott róla, hogy 
sikerült-e módosítani a személyes adatokat, például feliratkozni a hírlevélre. A feladatmegoldás során keletkező scan path vizualizáció ez esetben is igazolja, hogy a felhasználók valóban nehezen találták meg a hírlevél feliratkozás lehetőségét és tekintetük bejárta a felhasználói felület egészét a „Módosítás” gombra történő kattintás után (10. ábra).

\section{5. Összefoglalás}

Az esettanulmányokból jól látható, hogy az asztali szemmozgáskövetés kiválóan alkalmazható az e-kereskedelemben weboldalak és webáruházak használhatósági vizsgálatára. A technológia alkalmazása lehetővé teszi a vizuális ingerekre adott tudattalan reakciók mérését, így az egyén viselkedésének átfogó megismerését.

A használhatósági vizsgálatok során keletkező információk a szemmozgáskövetés segítségével vizualizálhatók, amelyek jól szemléltetik a feladatmegoldás körülményeit, így ezek az ábrák a termékfejlesztés alapját képezhetik, míg egy-egy érdeklődési területre további kvantitatív adatok is kinyerhetők a jelenségek számszerü igazolása érdekében.

A használhatósági vizsgálatoknál a szemmozgáskövetés mindig csak támogató technológiaként van jelen, hiszen az jól kiegészíti a már önmagában is rendkívül hasznos hangos gondolkodás módszerét. A hangos gondolkodás mint robosztus eszköz lehetővé teszi, hogy a felhasználók a termékhasználat során (vagy utána) feltárják a termékhasználat nehézségeit. Az így azonosított problémák pedig tekintetkövetéssel és utólagos interjúval összekötve többféle módon igazolják és teszik egyértelművé a termékfejlesztés szükségességét.

\section{Irodalom}

Allsop, Jonathan and Rob Gray, „Flying under pressure: Effects of anxiety on attention and gaze behavior in aviation”, ,Journal of Applied Research in Memory and Cognition, Vol. 3. (2014) Issue 2., pp. 63-71. http://dx.doi.org/10.1016/j.jarmac.2014.04.010.

Alshammari, Thamer, Obead Alhadreti és Pamela Mayhew, „When to ask participants to think aloud: A comparative study of concurrent and retrospective think-aloud methods", International Journal of Human Computer Interaction, Vol. 6. (2015) Issue 3., pp. 48-64.

Antalovits, Miklós és Süle Margit (szerk.), Termékmenedzsment. Budapest: Typotex, 2012.

Babicsné Horváth, Mária, Károly Hercegfi és Anna Hidas, „Mobile Eye-Tracking -based Usability Evaluation Method in Product Ergonomics: Presented via Various Case Studies", Book of Proceedings 7th International Ergonomics Conference (Zadar, Croatia, 13-16 of June 2018), 2018, pp. 43-50. 
Biswas, Pradipta and Pat Langdon, „A new input system for disabled users involving eye gaze tracker and scanning interface”, Journal of Assistive Technologies, Vol. 5. (2011) Issue 2., pp. 58-66. https://doi.org/10.1108/17549451111149269

Buswell, Guy Thomas, How people look at pictures: a study of the psychology and perception in art, Univ. Oxford, England: Chicago Press, 1935.

Buswell, Guy Thomas, „An Experimental Study of the Eye-Voice Span in Reading”, Issue Supplementary Educational Monographs, Vol. 17. (1920) No. 2.

Butsch, Rusell L. C., „Eye movements and the eye-hand span in typewriting.”, Journal of Educational Psychology, Vol. 23. (1932) Issue 2., pp. 104-121. https://doi.org/10.1037/h0073463

Cooke, Lynne, „Assessing concurrent think-aloud protocol as a usability test method: A technical communication approach”, IEEE Transactions on Professional Communication, Vol. 53. (2010) Issue 3., pp. 202-215. https://doi.org/10.1109/TPC.2010.2052859

Cornsweet, Tom N. and Hewitt D. Crane, „Accurate two-dimensional eye tracker using first and fourth Purkinje images”, Journal of the Optical Society of America, Vol. 63. (1973) Issue 8., pp. 921-928.

Delabarre, Edmund B., „A Method of Recording Eye-Movements”, The American Journal of Psychology, Vol. 9. (1898) Issue 4., pp. 572-574. https://doi.org/10.2307/1412191

Dodge, Raymond and Thomas Sparks Cline, „The angle velocity of eye movements”, Psychological Review, Vol. 8. (1901) Issue 2., pp. 145-157. https://doi.org/10.1037/h0076100

Doshi, Anup and Mohan Manubhai Trivedi, „On the Roles of Eye Gaze and Head Dynamics in Predicting Driver's Intent to Change Lanes”. ,Trans. Intell. Transport. Sys., Vol. 10. (2009) Issue 3., pp. 453-462. https://doi.org/10.1109/TITS.2009.2026675.

Dumas, Joseph S and Beth A Loring, Moderating Usability Tests : Principles and Practice for Interacting, Burlington: Morgan Kaufmann Publishers, Elsevier, 2008.

Fender, D. H., „Contact lens stability”, Biomedical sciences instrumentation, Vol. 2. (1964) Issue 1., pp. 43-52.

Goldberg, Joseph H. and Anna M. Wichansky, „Eye tracking in usability evaluation: A practitioner's guide”, Ralph Radach, Jukka Hyona és Heiner Deubel (szerk.), The Mind's Eye, Elsevier, 2003, pp. 493-516. https://doi.org/10.1016/B978-044451020-4/50027-X

Gulyás Szilvia, „Szemmozgások alatti eseményfüggő EEG változások”, Semmelweis Egyetem, 2009. http://semmelweis.hu/wp-content/phd/phd live/vedes/export/gulyasszilvia.d.pdf.

Haak, Maaike J van den and Menno DT de Jong, „Exploring two methods of usability testing: concurrent versus retrospective think-aloud protocols”. IEEE International Professional Communication Conference (Orlando, USA, 21-24 September 2003), 2003, pp. 285-287.

Hámornik, Balázs P., Hlédik Erika, Józsa Eszter és Lógó Emma, „Termékattribútumok vizuális keresése tejtermékek csomagolásán: az érdeklődési övezetek (AOI) kijelölésének két módszerének összehasonlítása”, 2013, 92-105. old.

Haupt, Corinna and Andrea B. Huber, „How axons see their way - Axonal guidance in the visual system”, Frontiers in Bioscience, Vol. 13. (2008) Issue 13., pp. 3136-3149. https://doi. org/10.2741/2915

Holmqvist, Kenneth, Marcus Nyström, Richard Andersson, Halszka Jarodzka, Richard Dewhurst és Joost van de Weijer (szerk.), Eye Tracking: A Comprehensive Guide To Methods And Measures, Oxford: Oxford University Press, 2011. 
Huey, Edmund Burke, The psychology and pedagogy of reading, New York: The Macmillan Company, 1968.

Jacob, Robert J. K. and Keith S. Karn, „Commentary on Section 4. Eye tracking in human-computer interaction and usability research: Ready to deliver the promises”, Ralph Radach, Jukka Hyona és Heiner Deubel (szerk.), The Mind's Eye: Cognitive and Applied Aspects of Eye Movement Research, Elsevier Science, 2003, pp. 573-605.

Józsa, Eszter and Balázs P. Hámornik, „Find The Difference! Eye Tracking Study on Information Seeking Behavior Using an Online Game”, Journal of Eye tracking Visual Cognition and Emotion, (2012).

Köles, Máté, Balázs P. Hámornik, Emma Lógó, Károly Hercegfi, Sarolta Tóvölgyi, „Experiences of a combined psychophysiology and eye-tracking study in VR”, in 5th IEEE International Conference on Cognitive Infocommunications (Vietri sul Mare, Italy, 5-7 November 2014), 2014, 373-376. old.

Komlodi, Anita and Károly Hercegfi, „Exploring cultural differences in information behavior applying psychophysiological methods”, in Proceedings of the 28th International Conference on Human Factors in Computing Systems (Atlanta, Georgia, USA, 10-15 April 2010), 2010, pp. 4153-4158. https://doi.org/10.1145/1753846.1754118

Koren, Zsolt, Emma Lógó and Bálint Szabó, „Visitor experiences in The Museum of Applied Arts of Budapest Interactions with ColourMirror”, 10th IEEE International Conference on Cognitive Infocommunications (Naples, Italy, 23-25 October 2019), 2019.

Korpás, Zoltán és Szabó Bálint, „Az online reklámok közvetlen hatásának vizsgálata a vásárlási döntésekre”, Marketing \& Menedzsment, 53. évf. (2019) 2. szám, 31-44. old.

Lenzner, Timo, Lars Kaczmirek and Mirta Galesic, „Left Feels Right: A Usability Study on the Position of Answer Boxes in Web Surveys”, Social Science Computer Review, Vol. 32. (2014) Issue 6., pp. 743-764. https://doi.org/10.1177/0894439313517532

Liversedge, Simon P and John M Findlay, „Saccadic eye movements and cognition”, Trends in Cognitive Sciences, Vol. 1 (2000) Issue 1., pp. 6-14. https://doi.org/10.1016/S1364$\underline{6613(99) 01418-7}$

Lupu, Robert Gabriel és Florina Ungureanu, „A survey of eye tracking methods and applications", Mathematics Subject Classification: 68U35,68N19,94A12, 2013.

Mackworth, NH and EL Thomas, „Head-mounted eye-marker camera.”, Journal of the Optical Society of America, Vol. 52. (1962) Issue 6., pp. 713-716. https://doi.org/10.1364/ JOSA.52.000713

Merchant, John, Richard Morrissette and James L Porterfield, „Remote Measurement of Eye Direction Allowing Subject Motion Over One Cubic Foot of Space”, IEEE Transactions on Biomedical Engineering, Vol. 21. (1974) Issue 4., pp. 309-317. https://doi.org/10.1109/ TBME.1974.324318

Nielsen, Jakob, „Why You Only Need to Test with 5 Users”, Nielsen Norman Group, 2000, https://www.nngroup.com/articles/why-you-only-need-to-test-with-5-users/

Van Nuys, Kelvin and Homer E Weaver, „Memory span and visual pauses in reading rhythms and melodies”, Psychological monographs, 1943.

Patmore, David W and R Benjamin Knapp, „Towards an EOG-based eye tracker for computer control”, in Annual ACM Conference on Assistive Technologies, Proceedings (California, USA, 15-17 april 1998), 1998, pp. 197-203. https://doi.org/10.1145/274497.274533 
Richardson, Daniel C. and Michael J. Spivey, „Eye-Tracking: Characteristics and Methods EyeTracking: Research Areas and Applications Encyclopedia of Biomaterials and Biomedical Engineering Eye-Tracking: Characteristics and Methods”, 2004. https://doi.org/ 10.1201/ $\underline{\mathrm{b} 18990-101}$

Riggs, Lorrin A. and Floyd Ratliff, „Visual acuity and the normal tremor of the eyes”, Science, Vol. 114 (1951) Issue 7., pp. 17-18. https://doi.org/10.1126/science.114.2949.17

Rogers, Yvonne, Helen Sharp and Jenny Preece, Interaction Design: Beyond Human - Computer Interaction, 3rd edition, Chichester: Wiley Publishing, 2011.

Rubin, Jeffrey, Dana Chisnell and Jared Spool, Handbook of Usability Testing: Howto Plan, Design, and Conduct Effective Tests, Indianapolis: Wiley Publishing, 2008.

Sekuler, Robert and Blake Randolph, Perception, Boston: McGraw-Hill Co, 2005.

Stevenson, S B, C K Sheehy, A Roorda and Scott B Stevenson, „Binocular eye tracking with the Tracking Scanning Laser Ophthalmoscope HHS Public Access”, Vision Res, Vol. 118. (2016), pp. 98-104. https://doi.org/10.1016/j.visres.2015.01.019.

Szabó, Bálint és Szederkényi Bence, „Reklámok figyelemre gyakorolt hatásának szemmozgáskövetéses vizsgálata”, Jel-Kép, 41. évf. 1. szám, 2020, 71-84. old.

Tinker, M. A., „A photographic study of eye movements in reading formulae.”, Genetic Psychology Monographs, 1928.

Tobii, „How does the calibration work?”, Tobii Eye Tracking Support, 2019. https://help.tobii. com/hc/en-us/articles/360023794433-How-does-the-calibration-work-

Tonbuloğlu, İsmail, „Using eye tracking method and video record in usability test of educational softwares and gender effects”, Procedia-Social and Behavioral Sciences, Vol. 103. (2013), pp. 1288-94.

Weaver, Homer E., „A survey of visual processes in reading differently constructed musical selections”, Psychological Monographs, Vol. 1. (1943) Issue 55., pp. 1-30.

Weinschenk, Susan, 100 Things Every Designer Needs to Know About People. 1st edition, New Riders Publishing, USA, 2011.

Yarbus, A. L., „Role of eye movements in the visual process.”, 1965, pp. 167.

Young, L. R., „Recording Eye Position”, Biomedical Engineering Systems, New York: McGraw-Hill Co, 1970. 